ионы металлов и кислотные остатки, ионы металлов взаимодействует с гидроксид-ионом $\mathrm{OH}^{-}$ и образуется осадки металлов. Таким оброзом, на основание описанных реакция процесс озонирование может быть использован для удаления из сточных вод солей ряд тяжёлых металлов: сульфаты, карбонаты металлов и др.

\section{Библиографический список}

1.S. Nagib, K. Inoue. Recovery of lead and zinc from fly ash generated from municipal incineration plants by acid and/or alkaline leaching, Hydrometall. K., 2000.

2.C.A. Pickles, A. McLean, C.B. Alcock. Investigation of a new technique for the treatment of steel plant waste oxides. Adv. In Extractive Metallurgy. Ins. Mining, Metallurgy. London. 2000.
3.Hasanov A.S., Tolibov B.I., Pirnazarov F.G. Advantages of low-temperature roasting of molybdenum cakes // International scientific-practical conference on the theme: «International science review of the problems and prospects of modern science and education» - Boston (USA), 2019. - P17-18

4.Хасанов А.С., Толибов Б.И., Сирожов Т.Т., Ахмедов М.С. Новые направления по созданию технологию грануляции шлаков медного производства // Евразийский союз ученых \#2 (71), 2020. - С49-55

5.Хасанов А. С., Толибов Б. И. Исследование возможности процесса окисления сульфидных материалов в печи для интенсивного обжига // Горный журнал №9, 2018. -C85-89. DOI: 10.17580/gzh.2018.09.14.

http://www.rudmet.ru/journal/1758/article/30103/

\title{
APPLICATION OF THE DEVICE FOR RECEIVING AND TRANSFER OF SEEDS IN THE TECHNOLOGY FOR PREPARATION OF LOWERED SEEDS AND SUBSTANTIATION OF THE BASIC PARAMETERS
}

\author{
DOI: $\underline{10.31618 / \text { ESU.2413-9335.2020.3.74.749 }}$ \\ Djamolov Rustam Kamolidinovich \\ c.t.s, scientific senior employ \\ of "Pakhtasanoat Ilmiy Markazi” JSC, \\ Uzbekistan
}

\begin{abstract}
The article analyzes the development of technology for the preparation of pubescent sowing seeds, based on the effectiveness of the development of a device for receiving and transferring pubescent seeds and its application in technology. The results of determining the optimal size of the device for receiving and transmitting pubescent seeds by the method of mathematical planning of experiments are presented.

As a result of determining the optimal size of the pubescent seed receiving and transmitting device (UPS) by the method of mathematical planning of experiments, the pitch of the screw conveyor is $165 \mathrm{~mm}$, the rotation speed of the screw conveyor is $20 \mathrm{rpm}$, the guide-adjuster and the distance between the screws were $50 \mathrm{~mm}$.

Keywords. Pubescent seeds, technology, device, UPS, reception and transmission, mathematical planning, screw conveyor, rotation speed, experiment.

Introduction. One of the factors in boosting the economy of the Republic of Uzbekistan is to increase the efficiency of cotton growing, increase the volume and quality of products from raw cotton.

In doing so, cotton seed and seed quality are of great importance.

Currently, in the Republic of Uzbekistan are sown mainly 2 types of seeds - hairy and dehydrated seeds. Quality indicators of these seeds UzDSt 663: 2017 "Seeds. Specifications "standard.

Seed preparation shops ensure that the seeds meet the standard requirements.

The ginneries of Uzpakhtasanoat JSC had 118 treatment and 50 seed decontamination shops. The large number of workshops did not allow the use of modern, high-performance equipment with low labor costs.

The placement of the seeds in the sacks was done by hand, the amount of seeds in the sacks was determined by "eye", and the mouths of the sacks were sewn by hand with poor quality, resulting in the loss of seed material.

In order to ensure the implementation of the Resolutions of the Cabinet of Ministers of the Republic of Uzbekistan No. 604 of December 23, 2004 and No.

4 of January 5, 2005, the technology and equipment of existing seed production workshops were re-analyzed. In these workshops, there is a mismatch between the existing seed sorting equipment and the treatment equipment, or the low productivity of the sorting equipment, the lack of mechanized transfer of seeds to the technology, ie manual execution, low quality of sorting machines, quality and appearance (design). incomplete compliance with modern requirements, visual determination of the amount of drug in the process of treatment, etc. confirmed the presence of deficiencies.

Current status and analysis of the problem under consideration. Hairy seed seed preparation technology involves the following basic processes: cleaning the seed from contaminants, sorting, curing, and placing it in paper bags.

Previously (until 1995), these processes were carried out using the simplest equipment, mainly manual labor. Seeds are transferred to the production of seeds by hand, using a shovel. This has led to a decrease in the efficiency of the machines without ensuring the uniform delivery of seeds to the sorting machines [1].

The hairy seeds were first placed at the beginning of the technological process with a manual shovel on
\end{abstract}


the auger 1, which was passed to the USM-A seed cleaning unit 2 for cleaning the auger seeds (Fig. 1).

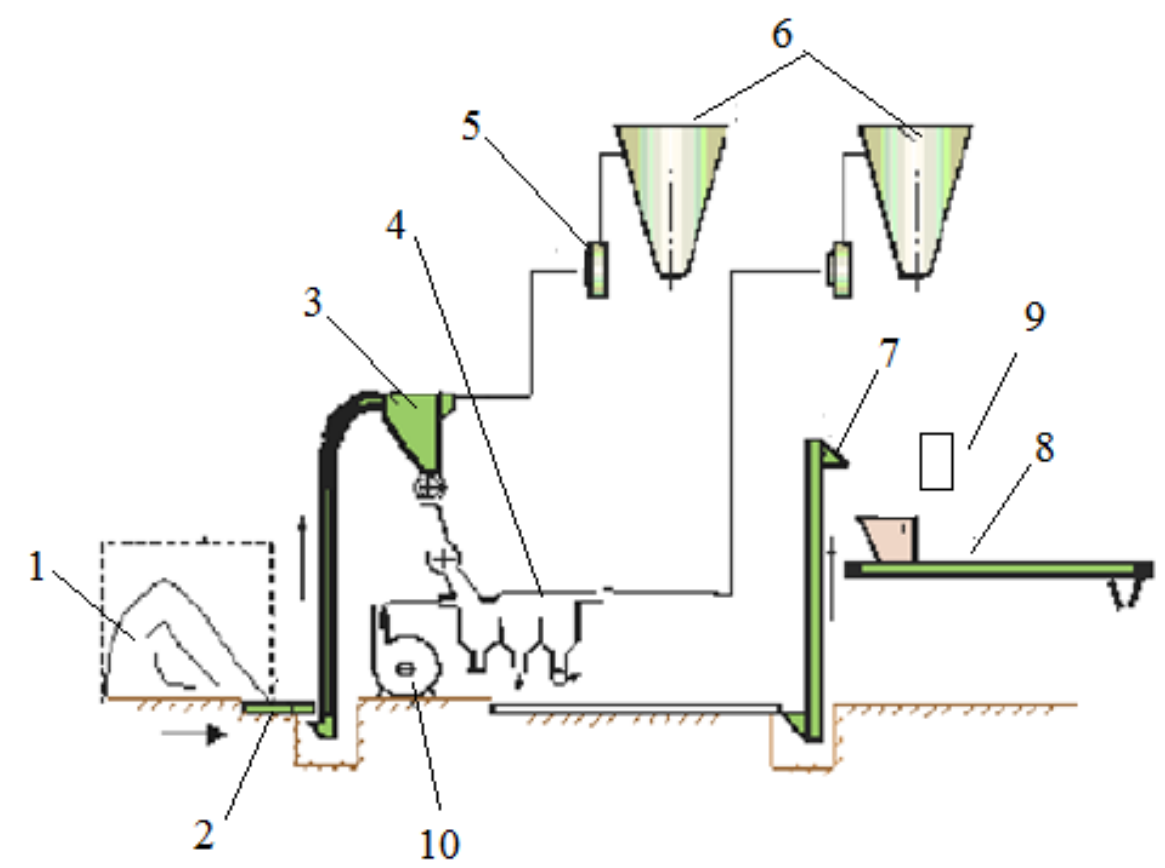

1-haired seed bunch, 2-seed screw, 3-cleaning machine USM-A, 4-seed sorter SPS, 5-fan VTs-8, 6-cyclone TsP-3, 7-elevator, 8-dispenser, 9-drug suspension tank, 10 - fan UVTS-22,

Figure 1. Schematic diagram of the sequence of technological equipment for the preparation of seeds, which existed until 1995.

The seeds from the USM-A cleaning machine 3 were passed to the SPS seed sorting unit 4, which was sorted in a horizontal air stream using fans 5 and 10 . The selected seeds were passed through an elevator 7 to a screw feeder 8 for treatment. The seeds treated in the bag were placed in three-ply paper bags, and the necks of the bags were sewn by hand by the operator.

The working efficiency of USM-A feather seed cleaning machine is not more than $7500 \mathrm{~kg} / \mathrm{h}$, the efficiency of cleaning from fine contaminants is 20 $25 \%$. The operating efficiency of the hair seed sorting equipment installed on the next line of technology (SPS) is $4000-6500 \mathrm{~kg} / \mathrm{h}$. Seed augers were used for the dosing process and the drug suspension was visually adjusted, resulting in many cases of drug overdose and seed moisture content exceeding the standard requirement.

Since 1995, the equipment equipped with a mechanical seed cleaner (MCS) of the hairy seed sorting unit (CHSA) has been introduced into the industry [2, 3]. With the introduction of these aggregates, there was an opportunity for additional mechanical cleaning of seeds, which significantly increased their quality. At the same time, additional tools were reduced, such as fans and elevators, which allowed to reduce the energy consumption of the equipment by $30-40 \%$, reducing mechanical damage to the seeds. The sequence diagram of this technology is shown in Figure 2. 


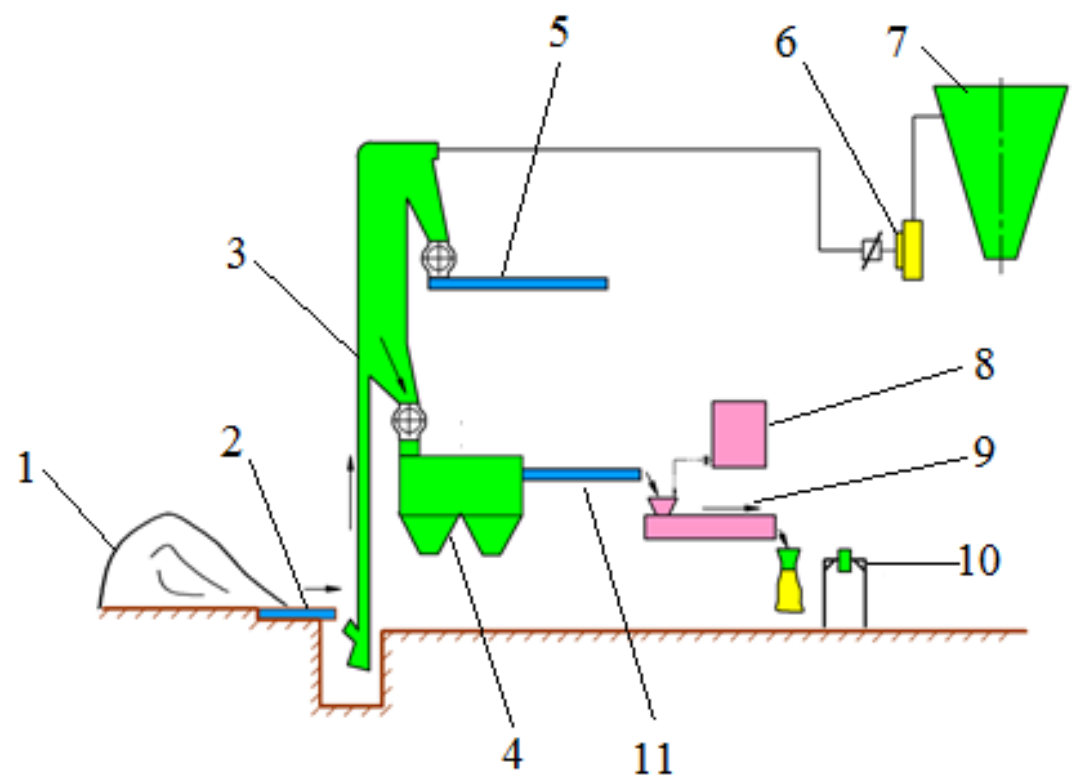

1-feather seed pile, 2- auger, 3-ChSA seed sorting unit; 4-mechanical seed cleaner MChT; 5-technical fraction auger, 6-fan VTS-8, 7-cyclone TSP-3, 8-drug suspension tank, 9-screw auger; 10-tin sewing machine, 11-technical fraction transmission screw.

Figure 2. Scheme of placement of technological equipment for the preparation of hairy seeds, available in 1995-2005.

Although attention has been paid to sorting and decontamination at every stage of the development of the technology, the transfer of hairy seeds to the technology in a flat, defined manner remains a problem.

As a result of studying the technologies and equipment developed in Uzbekistan and abroad, especially the vehicles and sorting and calibration equipment installed in them, as well as their operation and deficiencies, the principle system of technological processes and equipment for the production of hairy seeds suitable for the conditions of the Republic Developed by the staff of the Seed Preparation Laboratory of JSC in the presence of the author (Fig. 3) $[4,5]$.

The main criteria for assessing seed quality in the preparation of hairy seeds are: achievement of high germination, achievement of germination capacity, reduction of contamination and mechanical damage to the seed, compliance with standard requirements. Studies by many scientists $[6,7,8,9]$ have shown that the first sorting of seeds by specific gravity and then sorting by size leads to an increase in seed quality.
Modern technology of seed production, developed according to the above criteria, includes the following processes and equipment:

-receipt and transfer of hairy seeds for production, pneumatic cleaning and sorting of seeds from contaminants, leveling with fluff reduction, pneumomechanical cleaning, temporary collection, treatment and packaging of seeds (Fig. 3).

In order to ensure the recommended productivity of the plant, a newly developed UPS seed receivingtransmission device was introduced into the technological process $[10,11,12]$. UPS reception, installation of a standard transmission device, mechanical damage to the seed caused by scattering of seeds in the process are prevented, and the transfer of seeds to production is carried out at a constant rate of productivity.

In order to ensure the uninterrupted operation of the hair seed preparation shop, two BDOS bunkerdosing units are installed in the shop for temporary collection of cleaned and sorted seeds and their normal transfer to treatment $[13,14]$. This ensures that the treatment process runs at high productivity. 


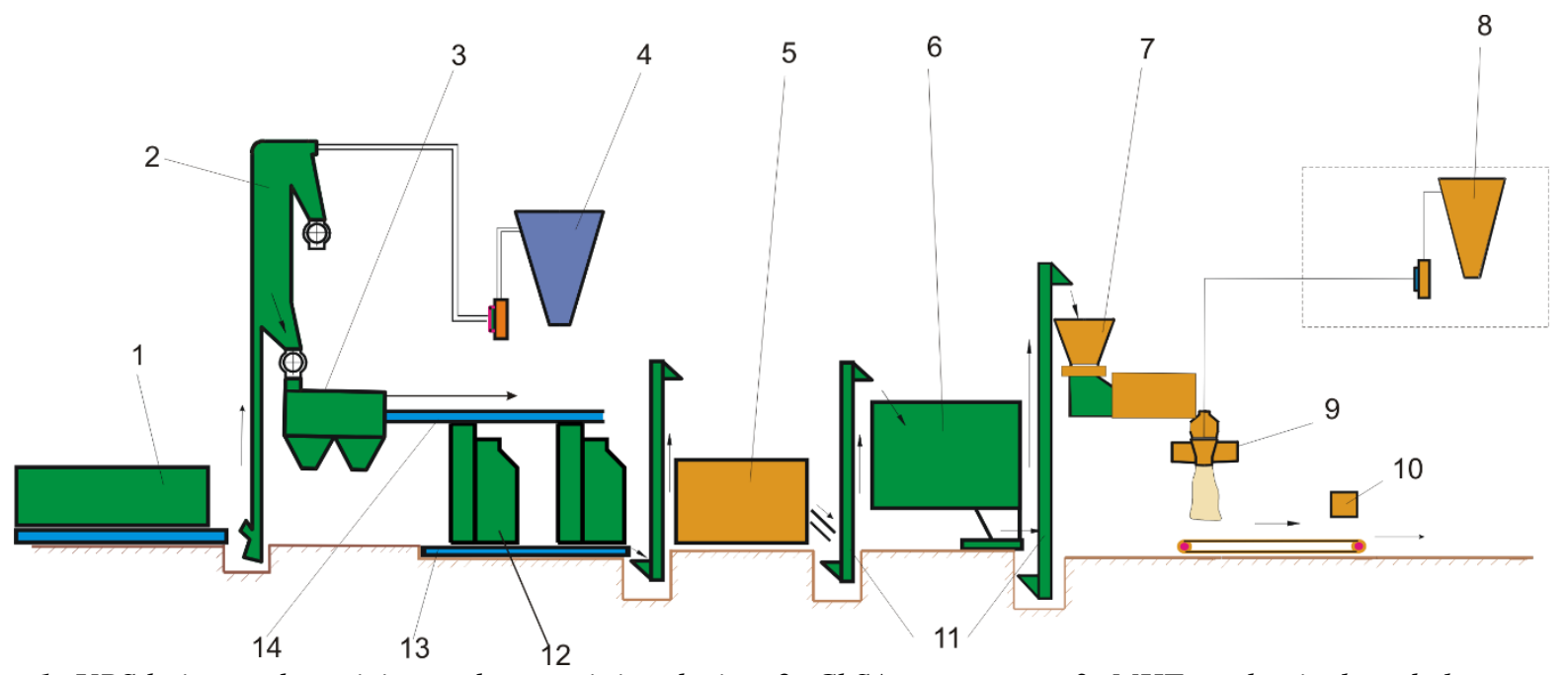

1- UPS hairy seed receiving and transmitting device; 2- ChSA aggregates; 3- MHT mechanical seed cleaner (included in the set of ChSA units); 4-cyclone; 5-feather seed sorting and cleaning machine;

6-BDOS bunker dispenser; 7- seed treatment machine; 8-aspiration device for air purification;

9- seed measuring device; 10 bag sewing machine; 11 - elevator; 12-5LP linters; 13-assembly screw conveyor; 14- distribution screw conveyor.

Figure 3. Schematic diagram of the installation of a system of technological equipment in a modern feather seed preparation shop.

In order not to increase the degree of mechanical damage to hairy seeds obtained from processing at ginneries according to the newly developed technological regulations for the initial processing of seed cotton, the degree of hair loss of lintered seeds should not exceed $9 \%$, mechanical damage should not exceed $1.8 \%$. . However, the high level of hairiness increases its sorting, cleaning error, and during sowing, the sowing machine gets stuck in the working parts and causes clogging. Therefore, in order to further linter the high-haired seeds and reduce the hair residue (up to 1$2 \%$ ) in the technological sequence process, two 5LP sawed linters were installed.

Lintered seeds are sent for pneumomechanical cleaning and sorting. There is a machine L-JS-4 / L of the Spanish company "Jubus", which performs cleaning and sorting 4 times, ie using the first air, twice through a sieve and again using air.
The treatment process is carried out in the Spanish firm Jubus D-2-VH [15, 16, 17].

The treated seeds are covered in the amount specified in the measuring device (for example, the measuring device of the Spanish firm Jubus B-JS-10 / S).

The placement of process equipment and machinery in the sequence in Figure 3 above allowed the system to be set to a working capacity of $3.0 \mathrm{tn} / \mathrm{h}$ to $4.0 \mathrm{tn} / \mathrm{h}$.

A schematic of the seed receiving and processing transmission device has been developed to ensure the continuous operation of the equipment in the system and the ability to unload the seed from the sidemounted trailer 2PTS-4-793 (Figure 4). The device is equipped with a screw conveyor 4 to transfer to it the production of spilled hair seeds. As the screws rotate, it directs the seed mass to production at an adjustable working capacity of up to 6 tons per hour. 

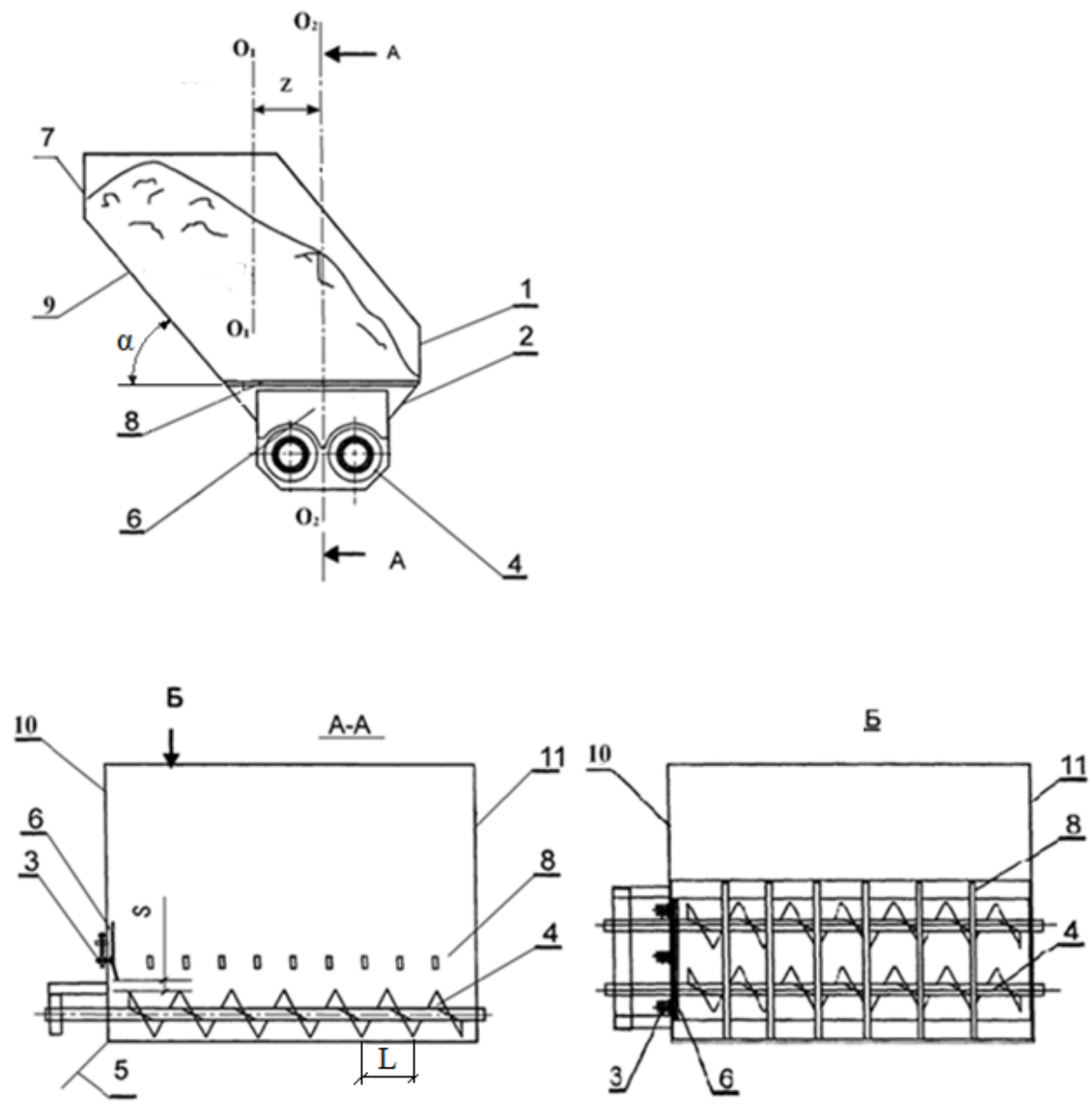

1-set, 2-platform, 3-adjusting screw mechanism, 4-screw conveyor, 5-rack, 6-guide-adjuster, 7-9-10-11-board part, 8-protective barrier grille.

$S$ - is the distance between the guide-adjuster and the screw; L-screw step. Figure 4. Hairy seed receiving-transmission UPS device.

The length of the working zone of the hairy seed receiving-transfer device was equal to the length of the trailer to prevent the seeds from being dumped in the hopper from spilling on the ground and was taken as $\mathrm{L}$ $=4800 \mathrm{~mm}$. Taking into account the consumption of 5 tons of hairy seeds per trailer, the capacity for the device bunker was $16 \mathrm{~m} 3$, knowing that the capacity of free-shedding hairy seeds is $280-320 \mathrm{~kg} / \mathrm{m}^{3}$. The angle of inclination of the two side boards along the length of the platform relative to the horizontal plane is determined by the angle of inclination of the board with respect to the horizontal plane. $=60^{\circ}$ was selected.

At the bottom of the platform 2 are mounted two screw conveyors (augers) 4, seed drill string 5, a screw mechanism 3 with a guide-adjuster 6 with a screw mechanism 3 on the platform frame, the set 1 , boards 9 , $7,10,11$ a protective barrier 8 is mounted on the top of the screw conveyors to ensure that the weight of the seed spilled on the platform does not put pressure on the screw conveyor and ensures the safety of the workers working.

As the UPS is a new device, there have been no previous scientific studies on it, and there have been problems in the normal transmission of spilled seed to production, while there have been no problems in receiving the seed from the trailer during operation. Tests were carried out by setting the number of screw conveyors from 1 to 3 . As a result, it was found expedient to take the number of conveyors as 2 .

Problem statement. Substantiation of the optimal dimensions of the UPS device in order to ensure the continuous transmission of seeds to the sorting unit $\mathrm{ChSA}$ at the specified rates, including:

-screw pitch of screw conveyor;

- rotation speed of the screw conveyor;

- the width of the seed hole from the platform, ie the distance between the guide-adjuster and the screw.

Solution methods. The optimal size of the UPS hairy seed receiving and transmitting device is determined by a mathematical planning method, in which the experiments used the multifactor PLANEXP-2 second-order V3 planning method $[18,19]$. In this case, the number of experiments is 14 , the number of returns is 3 and the number of factors is 3.

The results of the experiment, using computer applications, resulted in the initial processing of 
regression equations that adequately describe all the output parameters of the seed transfer process.

The problem of optimizing the optimal performance of the device was solved using EXCEL software and using a random search method.

Result analysis and examples. As a criterion for assessing the quality of seed transmission to the technological stage, the increase in mechanical damage of the seed transmitted from the device U1 and work productivity $\mathrm{U} 2$ were obtained. The main factors influencing the established criteria are: screw conveyor pitch h, screw conveyor rotation speed V, guideadjuster and screw spacing $\mathrm{S}$.

Based on preliminary experiments, the step and range of factors affecting seed transmission quality are given in Table 1. A photograph of the process device is shown in Figure 5.

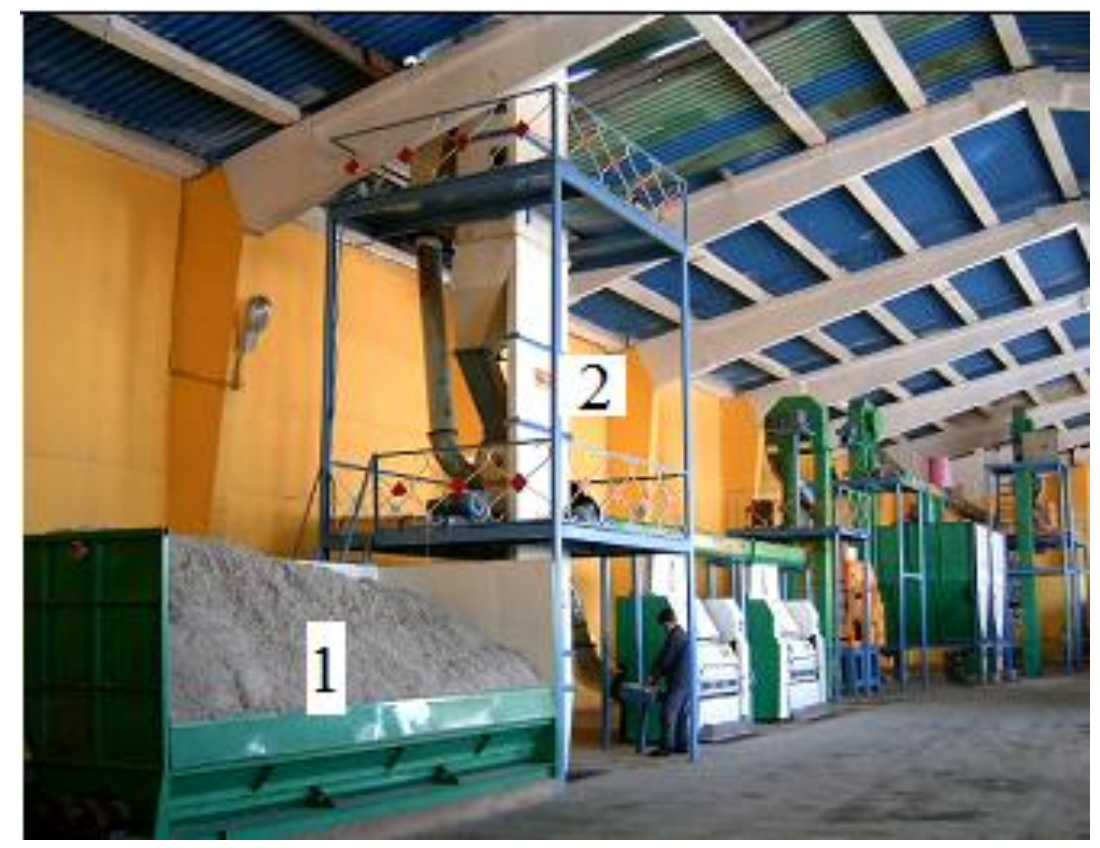

1-UPS type hair seed receiving and transmitting device, 2-ChSA type seed sorting unit. Figure 5. Photo of hairy seed preparation technology.

Table 1

Factor range and their steps

\begin{tabular}{|c|c|c|c|c|c|c|c|c|}
\hline \multirow{2}{*}{ № } & \multirow{2}{*}{ Factors } & \multirow{2}{*}{$\begin{array}{l}\text { Measurement } \\
\text { unit }\end{array}$} & \multicolumn{2}{|c|}{$\begin{array}{c}\text { Determination of } \\
\text { factors }\end{array}$} & \multirow{2}{*}{ Step } & \multicolumn{3}{|c|}{$\begin{array}{c}\text { Computational range of } \\
\text { factors } \\
\end{array}$} \\
\hline & & & straight & Coded & & -1 & 0 & +1 \\
\hline 1 & Screw conveyor step & $\mathrm{mm}$ & $\mathrm{h}$ & $\mathrm{X}_{1}$ & 20 & 140 & 160 & 180 \\
\hline 2 & $\begin{array}{l}\text { The rotational speed of the screw } \\
\text { conveyor }\end{array}$ & $\begin{array}{l}\text { turnover / } \\
\text { min }\end{array}$ & V & $\mathrm{X}_{2}$ & 5 & 15 & 20 & 25 \\
\hline 3 & $\begin{array}{l}\text { The distance between the guide- } \\
\text { adjuster and the screw. }\end{array}$ & $\mathrm{mm}$ & $S$ & $\mathrm{X}_{3}$ & 20 & 30 & 50 & 70 \\
\hline
\end{tabular}

The results of experiments conducted on the basis of the specified method of planning V3, the following regression equations were obtained using computer applications:

-increased mechanical damage to the seed.

$$
\mathrm{Y}_{1}=0.244+0.061 \mathrm{X}_{2}-0.063 \mathrm{X}_{3}+0.070 \mathrm{X}_{1}^{2}-0.039 \mathrm{X}_{1} \mathrm{X}_{2}-0.036 \mathrm{X}_{1} \mathrm{X}_{3}+0.073 \mathrm{X}_{2}^{2}+0.065 \mathrm{X}_{3}^{2}
$$

-performance of the device.

$$
Y_{2}=4136.666+255.833 X_{1}+975.500 X_{2}+538.500 X_{3}-528.166 X_{1}^{2}+39.583 X_{1} X_{2}+121.250 X_{2} X_{3}
$$

$\mathrm{n}$ checking the conformity of the obtained mathematical models, the satisfaction of the conformity condition was determined by comparing the calculated Fisher criteria and the table [20].

The issue of optimization was discussed in Excel in order to determine the optimal size of the device.
Boundary conditions:

U1 - increase in mechanical damage to the seed, less than $0.5 \%$ rest;

$\mathrm{U} 2$ - the operating capacity of the device is 4000 $\mathrm{kg} / \mathrm{h}$. 
The conditional optimization problem was solved using a random search method and modern computer applications, and the following optimal solutions were obtained (Table 2):

The result of optimizing the mathematical model

Table 2

\begin{tabular}{|c|c|c|c|}
\hline Factors & $\mathrm{X}_{1}$ & $\mathrm{X}_{2}$ & $\mathrm{X}_{3}$ \\
\hline Coded & 0,215447 & $-0,15819$ & $-0,02234$ \\
\hline Natural & 164,3089 & 19,20903 & 49,5532 \\
\hline Generalized & 165 & 20 & 50 \\
\hline
\end{tabular}

Thus, according to the results of the research, the screw conveyor pitch is $165 \mathrm{~mm}$, the rotation speed of the screw conveyor is $20 \mathrm{rpm}$, the distance between the guide-adjuster and the screw is $50 \mathrm{~mm}$.

Conclusion. As a result of studying the operation of technologies and equipment for seed production, its shortcomings, a technological system for the production of hairy seeds suitable for the conditions of the Republic has been developed. The optimal size of the UPS device recommended to the system was based on the normal transmission of the hairy seed to the technology.

The optimum dimensions of the hair seed seed receiving and transmitting device (UPS) were determined by mathematical planning method, resulting in a screw conveyor pitch of $165 \mathrm{~mm}$, a screw conveyor rotation speed of $20 \mathrm{rpm}$, and a guide-adjuster and screw spacing of $50 \mathrm{~mm}$.

\section{References}

1.V.G. Rakipov, R.K. Djamolov. Development and implementation of technological regulations for the preparation of technical requirements for workshop projects, preparation of hairy and dehydrated seeds using domestic, imported cleaning, sorting, calibration and treatment equipment. № 050901 Final report on research work, JSC "Pakhtasanoat Ilmiy Markazi", T2006. $-130 \mathrm{p}$.

2.Report of the Khlopkoprom NGO. Creation of a unit for cleaning and sorting pubescent sowing seeds of cotton, Topic 8808. Tashkent -1990. 126 p.

3.S.A.Saydakhmedov, V.N.Demakov, Z.Kh. Kasimov. Sorting and cleaning of cotton seeds in vertical air flow “Cotton industry". 1987, No 3, p.10.

4.T.M.Kuliev and R.K.Jamolov// State-of-the art process technique for conditionibg of sowing cotton seeds. Cotton research journal, India. Vol.8 №1. 2017. $-\mathrm{p} 8-11$.

5.Kuliev T.M., Rakipov V.G., Djamolov R.K. Technology of preparation of hairy seeds, patent for invention. № IAP 20180147.

6.Shleicher A.I. Experiments on the sorting of cotton seeds Cotton production, Tashkent, 1958, No. 5. $-21 \mathrm{p}$.
7.Koloyarov L.F., Tashlanov A.K. On the issue of sorting cotton seeds, “Cotton production” 1958, № 4.

8.Maysuryan N.A. Biological basis of sorting seeds by specific weight. Proceedings of the TSKhA issue 37, Moscow-1947 .- 22p.

9.Yasheva E.Ya. Sowing cotton with sorted seeds, "Agriculture of Uzbekistan", Tashkent,1961. No. 1. $21 \mathrm{p}$.

10.V.G.Rakipov， R.K.Djamolov， I.Sibgatullin, R.R.Nazirov. Development of a standard transmission device for the production of hairy seeds, Report on research work, №050903, JSC "Pakhtasanoat Ilmiy Markazi”, Tashkent 2006 y. -32p.

11.Koshakeev B.Ya., Gulyaev R.A., Rakipov V.G., Djamolov R.K. Hairy seed receiving-transfer bunker, utility model patent №FAP00855, 2013.

12.V.G.Rakipov, R.K.Djamolov. Instructions for Use, Installation and Adjustment of Hairy Seed Receiving Bunker (UPS), PDQI 80-2006 -9 p.

13.V.G.Rakipov, V.H. Toychiev. Development of a bunker-dispenser for hairy seeds, Report on the research work. Tashkent 1999, $-72 \mathrm{p}$.

14.A guide to the initial processing of cotton. Pakhtasanoat Scientific Center JSC, T-2019 -114 p.

15.Technological regulation of primary processing of seed cotton, PDI 50-2014. Tashkent 2014 y.-23 p.

16.Operating Instructions: Protectant Model D-2VH. JUAN BUSQUETS GRUSAT, S.A. REUS (ESPANA).

17.I.I. Novitsky. The study of some physical and mechanical properties of cotton seeds and the search for mechanisms to perform work with them. Cand. Diss., Tashkent, 1968, $120 \mathrm{p}$.

18.Dospehov B.A. Methodology of field experience - M .: Agropromizdat, 1985. - $351 \mathrm{p}$.

19.Vedinyapin G.V. General experimental research methodology and experimental data processing. M., Kolos, 1973.-184 p.

20.M.Augambaev, A.Ivanov, Yu.Terekhov. Fundamentals of planning a research experiment. Ukituvchi, T-2011, -336 p. 